\title{
Risk assessment by seasonal variation of well water fluoride in Japan
}

\author{
Ryouichi Satou $^{\mathrm{a}^{*}}$, Haruka Aikawa ${ }^{\mathrm{b}}$, Naoki Sugihara ${ }^{\mathrm{a}}$ \\ a Department of Epidemiology and Public Health, Tokyo Dental College, 2-9-18, Kandamisakicho, \\ Chiyodaku, Tokyo, Japan \\ b Department of Dental Hygiene, Tokyo Dental Junior College, 2-9-18, Kandamisakicho, \\ Chiyodaku, Tokyo, Japan \\ satouryouichi@tdc.ac.jp
}

Keywords: Fluoride, Risk assessment, Seasonal variation, hazard quotient, Well water This study clarified the existence of seasonal variations of Fluoride concentrations in multiple wells with different depths, and determined the appropriate time to assess chronic Fluoride toxicity considering these variations. There was up to 3.6 times more seasonal variation in $\mathrm{F}$ concentration at the same point. The mean F ion concentration was the lowest at $0.0766 \pm 0.0197 \mathrm{mg} / \mathrm{L}$ in March, and highest at $0.2412 \pm 0.0345 \mathrm{mg} / \mathrm{L}$ in December. The hazard quotients (HQ) were all $<1$ at all points, and the risk of chronic Fluoride toxicity in children was low. It is necessary to carry out multiple measurements, including in periods with low rainfall, due to seasonal variations.

\section{Introduction}

Fluoride $(\mathrm{F})$ has been reported to prevent dental caries by improving the acid resistance of teeth and promoting remineralization, and has a long history of use and results in preventive dental clinical practices [1-4]. In Japan, F application methods are limited to topical applications such as tooth surface application and mouth rinsing methods. Systemic applications such as water fluoridation and taking $\mathrm{F}$ tablets have not been implemented [5].Therefore, most of the $\mathrm{F}$ absorbed by the body comes from ingesting food and water, so it is important to accurately estimate the intake amount. In adults, more than $90 \%$ of ingested $\mathrm{F}$ is excreted in the urine. However, children are reported to have about $40 \%$ of the ingested $\mathrm{F}$ absorbed and translocated into their blood and bones, and thus $F$ ingestion puts them at greater risk for complications than adults [6]. It has been reported that mottled teeth can result from chronic F toxicity during childhood, and occurs when the concentration of $\mathrm{F}$ in drinking water exceeds $1.2 \mathrm{mg} / \mathrm{L}$ after frequent intake $[2,6]$. The relationship between $\mathrm{F}$ concentration in drinking water and dental fluorosis was also clarified in a clinical study in Japan [7-9]. Therefore, it is essential to gather basic data on the amount of $F$ ingested from water and food, in order to implement safe $\mathrm{F}$ application methods. It has been reported that self-injected groundwater, such as well water and hot springs, contains $\mathrm{F}$ 
ions eluted from its formation, and has a high concentration $[7,10]$. $\mathrm{F}$ exists in the ground as calcium fluoride and is eluted into groundwater, thus the $\mathrm{F}$ concentration in groundwater varies from region to region $[10,11]$. The $\mathrm{F}$ ion concentration in groundwater is measured without considering the season and time, and there are few reports that measure it multiple times and take seasonal variation into account. Kimitsu City, in the Chiba prefecture, is a rare area where there are several self-spray wells with different depths, all in the same general area. The purpose of this study was to clarify the existence of seasonal variations of $\mathrm{F}$ concentrations in multiple wells with different depths, and to determine the appropriate time to assess chronic F toxicity considering these variations. We did this by taking advantage of the regional characteristics of Kimitsu City, which offered many wells of different depths.

\section{Experimental part}

\section{Collection of well water samples}

Artesian ell water was collected every three months from December 2018 to September 2019, from six wells in Kimitsu City, in the Chiba prefecture, at different altitudes and depths. The sampling points were A) Shinmachi Well (650 m depth), B) the Kururi Tourism Exchange Center front water pumping plaza (650 m), C) Fujidaira sake brewing well (500 m); D) Takasawa well (450 m); E) the Tamaru family well (630 m); and F) the Kururi Kaido well (350 $\mathrm{m})$. At the point where the faucet was installed, samples were collected after letting it run for 1 minute. The locations of the sample collection sites re shown on the map data of the Geographical Survey Institute of Japan (Figure 1).

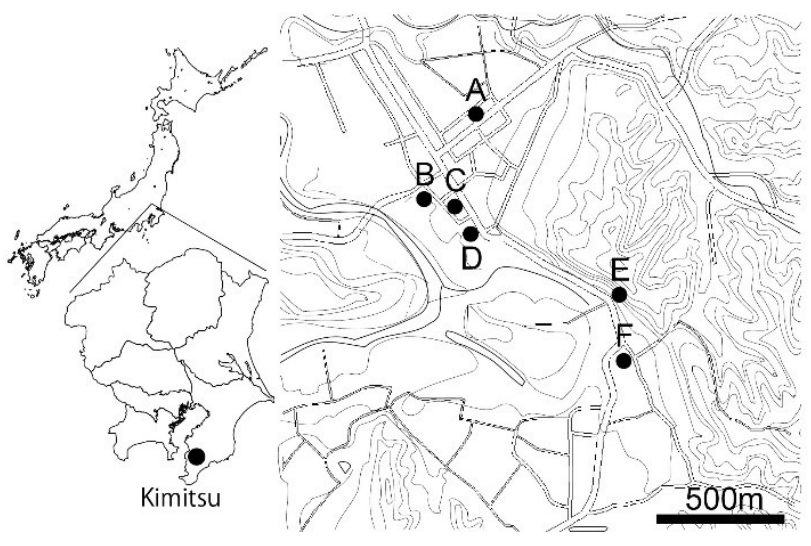

Figure 1. Location of well water sampling points.

The following is a map of the locations of the sampling points in Kimitsu City, Chiba prefecture. The contour lines and roads are shown in the map, and the sampling points at the six points (A, B, C, D, E, and F) are indicated by black circles in order, starting from the north. The black scale bar indicates $500 \mathrm{~m}$.

\section{Determination of F concentration}

Liquid samples were analyzed for $\mathrm{F}$ concentration by a fluoride combination ion selective electrode (9609BNWP, Thermo Science, Massachusetts, USA) and an ion meter (930A, Thermo Science, Massachusetts, USA). The standard F concentrations were 10, 1.0, and $0.1 \mathrm{mg} / \mathrm{L}$. TISAB III (total ionic strength adjustment buffer III solution, Sigma-Aldrich Co. LLC., Tokyo, Japan) was added to each sample at a ratio of 10 to 1 . F concentrations of samples were calculated by comparison with a standard curve using three standard ranges. 
Estimation of daily $\mathrm{F}$ consumption and risk assessment of $\mathrm{F}$ intake. The estimated daily $\mathrm{F}$ intake (DFI) and F intake risk due to the consumption of beverages were calculated using formulas (1) and (2), according to the methods recommended by the USEPA (2015) and previous research [12-19].

$$
\mathrm{CDI}=\mathrm{C} \times \mathrm{DI} / \mathrm{BW}
$$

CDI: chronic daily intake ( $\mathrm{mg} / \mathrm{kg} /$ day)

$\mathrm{C}: \mathrm{F}$ concentration $(\mathrm{mg} / \mathrm{L}$ or $\mathrm{mg} / \mathrm{kg})$

DI: Average daily intake rate of the preference beverage (L/day)

BW: Body weight (kg)

DFI: Daily F intake $(\mathrm{mg} /$ day $)=\mathrm{C} \times \mathrm{DI}$

CDI is defined as chronic daily intake $(\mathrm{mg} / \mathrm{kg} /$ day) and $\mathrm{C}$ is the $\mathrm{F}$ concentration from the beverages $(\mathrm{mg} / \mathrm{L}$ or $\mathrm{mg} / \mathrm{kg})$. DI is the average daily intake rate, which was based on the National Health and Nutrition Survey (2018) conducted by the Ministry of Health, Labor and Welfare in Japan. In this study, DI was set at 2 $\mathrm{L} /$ day, which is the upper limit of water intake for children. BW is their body weight $(\mathrm{kg})$. According to the USEPA (2015), the default weights for the children and adults were set to 20 $\mathrm{kg}$ and $70 \mathrm{~kg}$, respectively. In Japan, $20 \mathrm{~kg}$ is close to the average weight of a 6-year-old child. Multiplying $\mathrm{C}$ and DI results in the estimated daily F intake (DFI) (mg/day).

The hazard quotient (HQ) was calculated using the following formula (2) [12-19].

$\mathrm{HQ}=\mathrm{CDI} / \mathrm{RfD}$

HQ: Hazard Quotient
RfD: Reference dose

The reference dose (RfD) is an estimate of a daily exposure that is not expected to be related to a significant risk of adverse effects throughout life. The RfD of F is $0.06 \mathrm{mg} / \mathrm{kg} / \mathrm{day}$, which includes both $0.05 \mathrm{mg} / \mathrm{kg} /$ day due to $\mathrm{F}$ intake via beverages and $0.01 \mathrm{mg} / \mathrm{kg} / \mathrm{day}$ due to $\mathrm{F}$ intake via meals. When the HQ is $>1$, the estimated potential $\mathrm{F}$ exposure exceeds the RfD, and a risk of fluorosis is possible.

\section{Statistical analysis}

All data are expressed as the means of three replicates with standard deviation. Statistical analysis among the samples was performed by one-way analysis of variance (ANOVA), and differences were considered significant at $p<0.05$. The Bonferroni test was used for post-hoc comparisons when significance was determined by the analysis of variance $(p<0.05)$. All statistical analyses were performed with Origin 2019b software (version 9.6.5.169, LightStone, Tokyo, Japan).

\section{Results and discussion}

\section{Seasonal variation in $F$ ion concentration in well water}

The F ion concentrations in March, June, September, and December at each sampling point is shown in Figure 2. The F ion concentrations at sampling point A were $0.0703 \pm 0.0025 \mathrm{mg} / \mathrm{L}$ in March 2019, 0.1017 $\pm 0.0034 \mathrm{mg} / \mathrm{L}$ in June 2019, $0.1280 \pm 0.0041 \mathrm{mg} / \mathrm{L}$ in September 2019, and $0.2533 \pm 0.0082 \mathrm{mg} / \mathrm{L}$ in December 2018. There 
was a significant seasonal variation in the $\mathrm{F}$ ion concentration at point $\mathrm{A}$, with the lowest in March and the highest in December $(\mathrm{p}<0.05)$. The $\mathrm{F}$ ion concentration in December was approximately 3.6 times the concentration in March (Figure 2). Similarly, the Fluoride ion concentrations at point $\mathrm{B}$ were $0.0720 \pm 0.0008$ $\mathrm{mg} / \mathrm{L}$ in March, $0.1030 \pm 0.0022 \mathrm{mg} / \mathrm{L}$ in June, $0.1170 \pm 0.0016 \mathrm{mg} / \mathrm{L}$ in September, and 0.2333 $\pm 0.0053 \mathrm{mg} / \mathrm{L}$ in December. F ion concentration at point $\mathrm{C}$ was lowest in March at $0.1130 \pm$ $0.0008 \mathrm{mg} / \mathrm{L}$, in June at $0.1623 \pm 0.0031 \mathrm{mg} / \mathrm{L}$, in September at $0.1800 \pm 0.0016 \mathrm{mg} / \mathrm{L}$, and was the highest in December at $0.3000 \pm 0.0033$ $\mathrm{mg} / \mathrm{L}$. The $\mathrm{F}$ ion concentration at point $\mathrm{D}$ was $0.0723 \pm 0.0037 \mathrm{mg} / \mathrm{L}$ in March, $0.1000 \pm 0.0033$ $\mathrm{mg} / \mathrm{L}$ in June, $0.1147 \pm 0.0025 \mathrm{mg} / \mathrm{L}$ in September, and $0.2250 \pm 0.0049 \mathrm{mg} / \mathrm{L}$ in December. The $\mathrm{F}$ ion concentration at point $\mathrm{E}$ was $0.0783 \pm 0.0017 \mathrm{mg} / \mathrm{L}$ in March, $0.1113 \pm$ $0.0021 \mathrm{mg} / \mathrm{L}$ in June, $01283 \pm 0.0009 \mathrm{mg} / \mathrm{L}$ in September, and $0.2390 \pm 0.0037 \mathrm{mg} / \mathrm{L}$ in December. The $\mathrm{F}$ ion concentration at point $\mathrm{F}$ was $0.0537 \pm 0.0025 \mathrm{mg} / \mathrm{L}$ in March, $0.0773 \pm$ $0.0021 \mathrm{mg} / \mathrm{L}$ in June, $0.0957 \pm 0.0017 \mathrm{mg} / \mathrm{L}$ in September, and $0.1963 \pm 0.0026 \mathrm{mg} / \mathrm{L}$ in December. March was the lowest at all points $(\mathrm{A}-\mathrm{F})$, and the concentration gradually increased, with a tendency to peak in December (Figure 2). In addition, a significant difference in F concentration was observed between September and December at point B, March and December at point C, September and December at point $\mathrm{D}$, and March-December at point $\mathrm{F}$, compared with Point $\mathrm{A}$ as the reference in the same month $(p<0.05)$. In December when the F ion concentration was the highest, a comparison of the six sampling points revealed that point $\mathrm{C}$ had the highest concentration and point $\mathrm{F}$ had the lowest concentration.

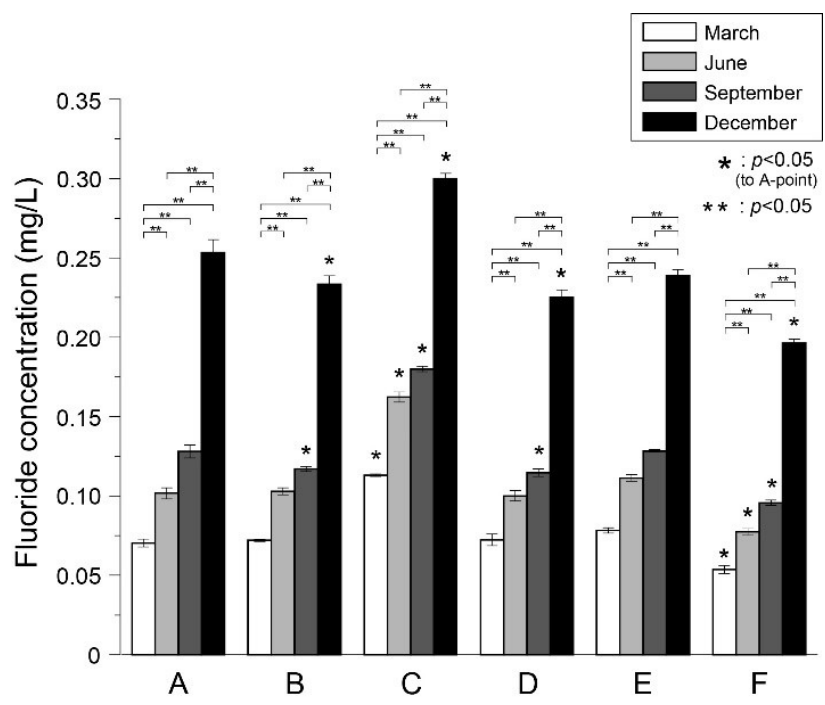

Figure 2. Well water $\mathrm{F}$ ion concentration by month at each sampling point.

The figure shows the monthly well water $F$ ion concentration at each sampling point. The F concentrations are displayed as the mean $\pm \mathrm{SD}$ from five replicates at each point. White boxes indicate March, gray boxes indicate June, dark gray boxes indicate September, and black boxes indicate December. * Indicates a significant difference compared to point $\mathrm{A}$ on the same month, calculated using a multiple comparison $(\mathrm{p}<0.05)$. ** indicates that there are significant monthly differences, calculated by a multiple comparison $(\mathrm{p}<0.05)$.

Figure 3 shows a comparison of the average values of $\mathrm{F}$ ion concentrations at the 6 points in the same month. The mean $\mathrm{F}$ ion concentration in each month was the lowest at $0.0766 \pm 0.0197 \mathrm{mg} / \mathrm{L}$ in March, $0.1093 \pm 0.0284$ 
$\mathrm{mg} / \mathrm{L}$ in June, $0.1273 \pm 0.0284 \mathrm{mg} / \mathrm{L}$ in September, and $0.2412 \pm 0.0345 \mathrm{mg} / \mathrm{L}$ in December. There were significant differences between all of the time points, and a clear seasonal variation was observed $(p<0.05)$ (Figure 3).

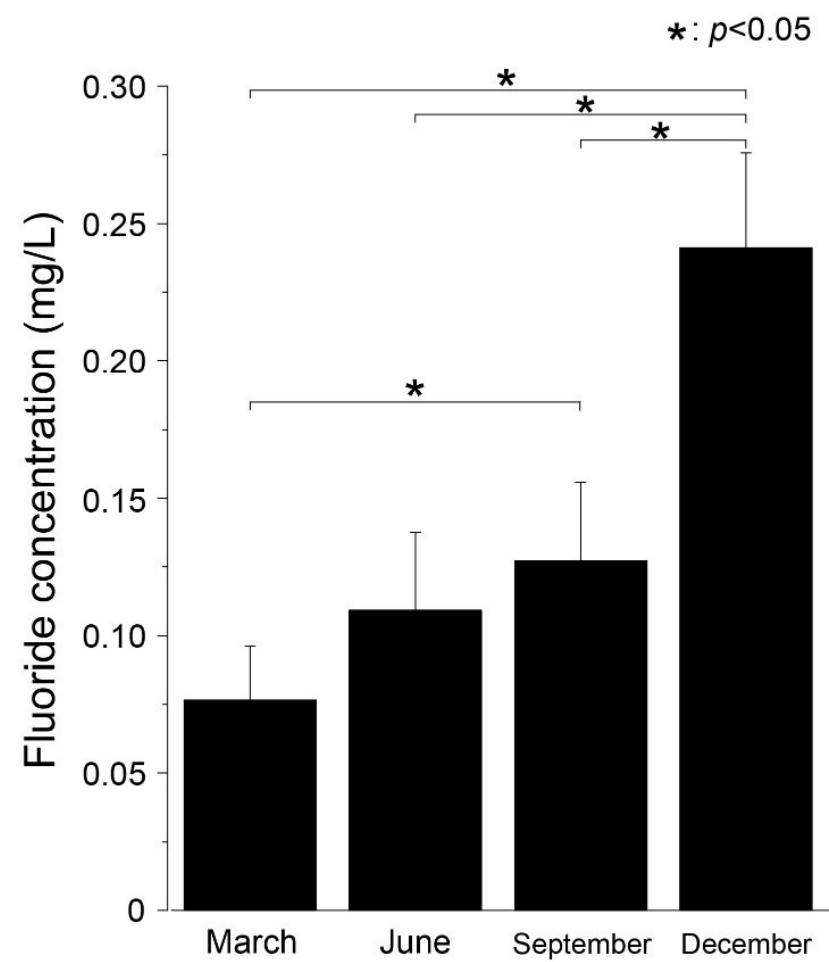

Figure 3. Seasonal variation of average well water $F$ ion concentration by month.

The figure shows the seasonal variation of the well water $F$ ion concentration, comparing the average values at the six points by month. F concentrations are displayed as the mean \pm SD per month. * Indicates a significant difference, calculated by a multiple comparison $(p<0.05)$.

\section{Estimation and risk assessment of F intake}

from well water

The CDI was calculated for the children according to the method established by the USEPA (1992). The CDI was $0.0138 \mathrm{mg} / \mathrm{kg} /$ day at point $\mathrm{A}, 0.0131 \mathrm{mg} / \mathrm{kg} / \mathrm{day}$ at point $\mathrm{B}, 0.0189$ $\mathrm{mg} / \mathrm{kg} /$ day at point $\mathrm{C}, 0.0128 \mathrm{mg} / \mathrm{kg} /$ day at point
$\mathrm{D}, 0.0139 \mathrm{mg} / \mathrm{kg} / \mathrm{day}$ at point $\mathrm{E}$, and 0.0106 $\mathrm{mg} / \mathrm{kg} /$ day at point $\mathrm{F}$. The CDI reflected the average $\mathrm{F}$ concentration at each point, with the highest value at sampling point $\mathrm{C}$ and the lowest value at point $\mathrm{F}$ (Table 1). The CDI did not exceed an RfD of 0.06 at all points, and it was about 0.3 at point $\mathrm{C}$, which had the largest CDI. All HQ values were $<1$, and the risk of chronic $\mathrm{F}$ toxicity in children was extremely low even with long-term intake (Table 1).

Table 1. Estimated $F$ daily Intake and hazard quotient from well water

\begin{tabular}{|c|c|c|c|c|}
\hline Point & DFI & CDI & RfD & HQ \\
\hline A & 0.2766 & 0.0138 & 0.06 & 0.2305 \\
\hline B & 0.2627 & 0.0131 & 0.06 & 0.2189 \\
\hline C & 0.3777 & 0.0189 & 0.06 & 0.3147 \\
\hline D & 0.2560 & 0.0128 & 0.06 & 0.2133 \\
\hline E & 0.2785 & 0.0139 & 0.06 & 0.2321 \\
\hline F & 0.2115 & 0.0106 & 0.06 & 0.1763 \\
\hline
\end{tabular}

DFI: Daily fluoride intake (mg/day), CDI: Chronic daily intake (mg/kg/day), RfD: Reference dose (mg/Kg/day), HQ: Hazard Quotient

From the results of the $\mathrm{F}$ ion concentration in March, June, September 2019, and December 2018 at each sampling point, it became clear that the $\mathrm{F}$ ion concentration shows a seasonal variation even at the same sampling points (Figure 2 and 3). Seasonal variation at all measured points was the smallest in March, and showed a gradual increasing trend until December. These results suggest that the cause of seasonal variation is not a sampling-point specific factor, but a widespread common factor 
such as temperature and rainfall. In the KöppenGeiger climate classification, Japan fluctuates between a temperate humid climate and a cold humid climate, whereas much of the rest of world has four distinct seasons. In addition, Japan has an annual temperature range that is larger than the daily range. It is also characterized by a large amount of precipitation, and experiences a large annual change in precipitation due to the rainy season and autumn rain. Figure 4 shows the changes in annual average temperature and annual average precipitation in Kimitsu City, Chiba prefecture, created from data from the Japan Meteorological Agency. Kimitsu City has the lowest rainfall at $69 \mathrm{~mm}$ in December, and the dry season ends in March; then the rainfall gradually increases. There is a close relationship between the amount of groundwater and the amount of rainfall. Therefore, it is estimated that the $\mathrm{F}$ ion concentration is relatively decreasing in March due to the increase in the amount of stored water (Figure 4). From March to June and September, Japan is in summer, and the average temperature rises. In August, the maximum temperature falls, and the amount of precipitation decreases (Figure 4). Seasonal variations in $\mathrm{F}$ concentrations in groundwater have also been reported in India and Iran, compared in summer and winter [20,21]. In this study, it was clarified that the $\mathrm{F}$ ion concentration in well water shows large seasonal variations in regions where the temperature and precipitation change significantly, including in Japan. This suggests that it is necessary to measure $\mathrm{F}$ concentration during the period of low precipitation multiple times, and obtain an average value for an accurate risk assessment.

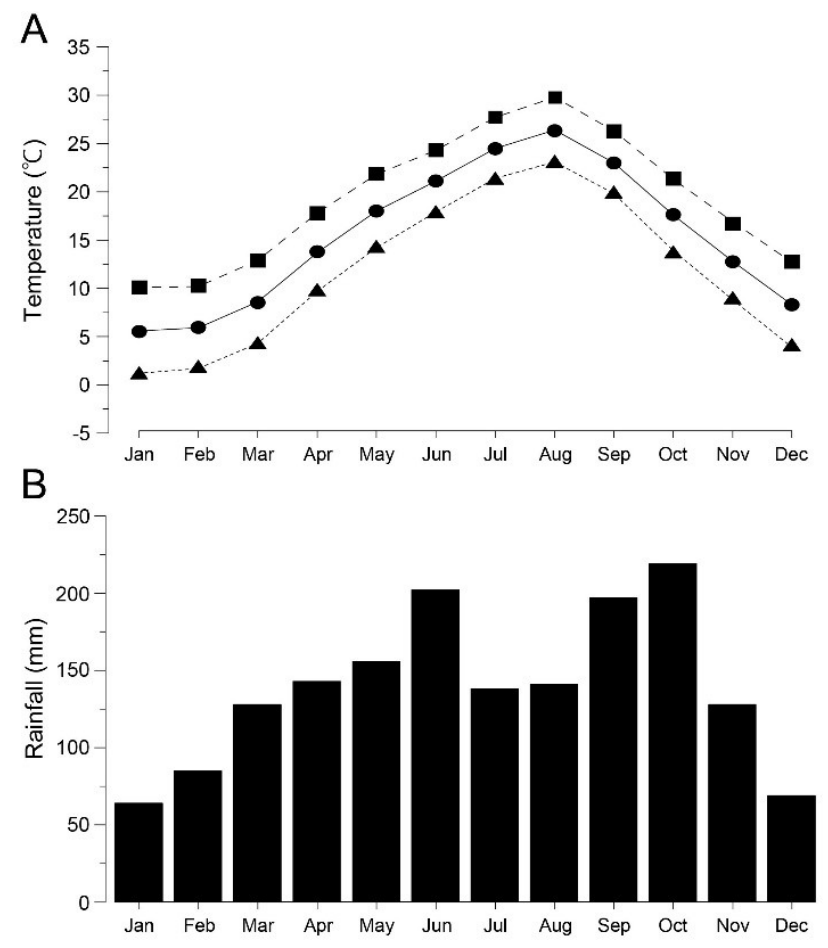

Figure 4. Changes in annual temperature and annual precipitation in Kimitsu City.

(A) Monthly temperature changes in Kimitsu City, Chiba prefecture. The square mark dotted line shows the maximum temperature. The round mark solid line shows the average temperature, and the triangle mark dotted line shows the minimum temperature. (B) Changes in monthly precipitation in Kimitsu City.

When comparing the same month, the well water $F$ concentration at each time point was different, even if the water source was the same. It is considered that the $\mathrm{F}$ concentration may change due to the depth and formation of the well. According to the research by Iijima et al., the concentration of $\mathrm{F}$ ions in groundwater is likely to be eluted from the sandy siltstone that exists in the stratum at a specific depth [10]. There are 109 
many sandy siltstones in the geology around the watershed, which are targeted for the excavation of wells. In previous research, it was also reported that the concentration of $\mathrm{F}$ ions was high in hot spring water that self-injected from a depth of $360-600 \mathrm{~m}$, which is close to the well depth of $450-650 \mathrm{~m}$ used in this research. In addition, the amount of water discharged from each well per minute was $20 \mathrm{~L} / \mathrm{min}$ for $\mathrm{A}$ and $\mathrm{B}, 8 \mathrm{~L} / \mathrm{min}$ for $\mathrm{C}$, $17.6 \mathrm{~L} / \mathrm{min}$ for $\mathrm{D}$, and $30 \mathrm{~L} / \mathrm{min}$ for $\mathrm{E}$ and $\mathrm{F}$. It is also possible that differences in the time to elute $\mathrm{F}$ from the formation during the self-injection and the difference in the amount of water stored in the well affected the fluorine concentration.

All $\mathrm{HQ}$ values were $<1$, indicating that the risk of chronic $\mathrm{F}$ toxicity in children is extremely low, even with long-term intake (Table 1). This result is similar to previous studies conducted in other regions $[18,19]$. However, when the HQ was calculated from the $\mathrm{F}$ ion concentration at point $\mathrm{C}$ in December, at the highest concentration, it was 0.50 , and the CDI increased to 0.5 , though it was still less than 1 (Table 1). It is important to consider that there may still be a high risk of $F$ toxicity even if the water source is the same, as it depends on the specific sampling point and can vary seasonally. It is also necessary to consider the possibility that seasonal fluctuations in fluoride concentration affect the onset of caries.

\section{Conclusions}

In this study, it was found that the F ion concentration of well water varied depending on the sampling point, and there was up to 3.6 times more variation in $\mathrm{F}$ concentration at the same point. The factors that influence the $\mathrm{F}$ ion concentration in well water are considered to be the depth of drilling, formation method, and amount of elution from the well. In addition, the changes in temperature and precipitation are estimated to factors of seasonal variation. The CDI did not exceed an RfD 0.06 of at all points, and it had the largest CDI at point $\mathrm{C}$ at 0.3 . All $\mathrm{HQ}$ values were $<1$, and the risk of chronic $\mathrm{F}$ toxicity in children was extremely low even with long-term intake. It was suggested that when calculating HQ for safe $F$ application, it is necessary to carry out multiple measurements, including in periods with low rainfall, taking into account seasonal variations.

\section{Acknowledgements}

We sincerely thank the Oral Health Science Center, Tokyo Dental College, for allowing us to use its facilities. We would like to thank Editage (www.editage.jp) for English language editing.

\section{References}

[1] Marinho VCC, Higgins JPT, Logan S, Sheiham A. Topical fluoride (toothpastes, mouthrinses, gels or varnishes) for preventing dental caries in children and adolescents. Cochrane Database Syst Rev 2003:CD002782.

https://doi.org/10.1002/14651858.CD002782.

[2] Iheozor-Ejiofor Z, Worthington HV, Walsh T, O’Malley L, Clarkson JE, Macey R, et al. Water fluoridation for the prevention of dental caries. Cochrane 
Database Syst Rev 2015:CD010856. https://doi.org/10.1002/14651858.CD010856.pub2.

[3] Marinho VCC, Worthington HV, Walsh T, Chong LY. Fluoride gels for preventing dental caries in children and adolescents. Cochrane Database Syst Rev 2015:CD002280.

https://doi.org/10.1002/14651858.CD002280.pub2.

[4] Marinho VCC, Chong LY, Worthington HV, Walsh T. Fluoride mouthrinses for preventing dental caries in children and adolescents. Cochrane Database Syst Rev 2016;7:CD002284.

https://doi.org/10.1002/14651858.CD002284.pub2.

[5] Takefuji Y. Dental fluoride policy in Japan. Br Dent J 2019;227:71-71. https://doi.org/10.1038/s41415019-0566-2.

[6] Srivastava S, Flora SJS. Fluoride in Drinking Water and Skeletal Fluorosis: a Review of the Global Impact. Curr Environ Health Rep 2020. https://doi.org/10.1007/s40572-020-00270-9.

[7] Matsuda K, Harada U, Iijima Y, Tazawa M, Takaesu Y. The chemical components of drinking water in a dental fluorosis area, Kitatsugaru. J Dent Health 1977;27:8-14. https://doi.org/10.5834/jdh.27.8.

[8] Ishii T, Kato K, Sakakibara Y. Review of literatures about dental fluorosis in Japan. J Dent Health 1982;32:78-102. https://doi.org/10.5834/jdh.32.78.

[9] Iijima Y, Tazawa M, Matsuda K, Nara Y, Kumeta T, Takaesu Y. Epidemiological Study of Appearance of Dental Fluorosis Related to Fluoride Concentrations in Drinking Water in Kitatsugaru, Japan. J Dent Health 1978;28:285-94. https://doi.org/10.5834/jdh.28.285.

[10] Iijima $Y$, Inaba D, Miyazawa M, Tazawa M, Katayama T. Stratigraphic Analysis of Fluoride Concentration in Soil from a Fluoride Area (Kitatsugaru). J Dent Health 1985;35:378-83. https://doi.org/10.5834/jdh.35.378.

[11] Haresaku S, Aida J, Oishi K, Oishi E, Taura K, Tsutsui A, et al. Relationship between the Granitoid Distribution and Fluoride Level in Drinking Water. J Dent
Health2011;61:203-8. https://doi.org/10.5834/jdh.61.2_203.

[12] US EPA O. Guidelines for Carcinogen Risk Assessment. US 2013. https://www.epa.gov/risk/guidelines-carcinogen-riskassessment .

[13] US EPA O. Guidelines for Human Exposure $\begin{array}{lll}\text { Assessment. US } & \text { EPA }\end{array}$ https:/www.epa.gov/risk/guidelines-human-exposureassessment.

[14] Waugh DT, Potter W, Limeback H, Godfrey M. Risk Assessment of Fluoride Intake from Tea in the Republic of Ireland and its Implications for Public Health and Water Fluoridation. Int J Environ Res Public Health 2016;13. https://doi.org/10.3390/ijerph13030259.

[15] Qasemi M, Farhang M, Biglari H, et al. Health risk assessments due to nitrate levels in drinking water in villages of Azadshahr, northeastern Iran. Environ Earth Sci 2018;77(23):782. https://doi:10.1007/s12665-018-7973-6

[16] Rezaei H, Zarei A, Kamarehie B. Levels, et al. Distributions and Health Risk Assessment of Lead, Cadmium and Arsenic Found in Drinking Groundwater of Dehgolan's Villages, Iran. Toxicol Environ Health Sci 2019;11(1):54-62. https://doi:10.1007/s13530-019-0388-2

[17] Mohammadi AA, Zarei A, Majidi S, et al. Carcinogenic and non-carcinogenic health risk assessment of heavy metals in drinking water of Khorramabad, Iran. MethodsX 2019;6:1642-1651. https://doi:10.1016/j.mex.2019.07.017

[18] Perumal E, Paul V, Govindarajan V, Panneerselvam L. A brief review on experimental fluorosis. Toxicol Lett 2013;223(2):236-251. https://doi:10.1016/j.toxlet.2013.09.005

[19] Keshavarz S, Ebrahimi A, Nikaeen M. Fluoride exposure and its health risk assessment in drinking water and staple food in the population of Dayyer, Iran, in 2013. J Educ Health Promot 2015;4. https://doi:10.4103/22779531.171785

[20] Pandith M, Malpe DB, Rao AD, Rao PN. Aquifer wise seasonal variations and spatial distribution of major 
ions with focus on fluoride contamination-Pandharkawada

block, Yavatmal district, Maharashtra, India. Environ

Monit Assess 2016;188:72.

https://doi.org/10.1007/s10661-015-5027-z.

[21] Yousefi M, Asghari FB, Zuccarello P, Oliveri Conti G, Ejlali A, Mohammadi AA, et al. Spatial Distribution Variation and Probabilistic Risk Assessment of Exposure to Fluoride in Ground Water Supplies: A Case Study in an Endemic Fluorosis Region of Northwest Iran. Int J Environ Res Public Health 2019;16. https://doi.org/10.3390/ijerph16040564. 